\title{
Digestibility of sweet potato vines in diets for growing rabbits
}

\section{Digestibilidade do baraço de batata-doce em dietas para coelhos em crescimento}

\section{Digestibilidad de hojas de batata-dulce en dietas para conejos en crecimiento}

\author{
Ana Carolina Kohlrausch Klinger ${ }^{1}$, Diuly Bortoluzzi Falcone ${ }^{2 *}$, Luiza de Sales Alves Prates ${ }^{3}$, \\ Geni Salete Pinto de Toledo ${ }^{4}$, Leila Picolli da Silva ${ }^{4}$ \\ ${ }^{1}$ Doutora em Produção Animal - Universidade Federal de Santa Maria (UFSM) \\ ${ }^{2}$ Mestre em Produção Animal - Universidade Federal de Santa Maria (UFSM) \\ 3Zootecnista Autônoma \\ ${ }^{4}$ Professora, Doutora e Pesquisadora da Universidade Federal de Santa Maria (UFSM) \\ *E-mail: diulybortoluzzi@gmail.com
}

\begin{abstract}
In developing countries, animal production is affected by the dependence on conventional ingredients or by its high cost, for which it is important to research agro-industrial by-products. Therefore, the purpose to this study was to evaluate the digestibility of diets for rabbits with sweet potato vines, in substitution to alfalfa hay. A biological essay was conducted to determine sweet potato vines digestibility, which took 12 days ( 5 for adaptation and 7 for collecting feces). A total of 27 rabbits received three different diets: reference (0SPV) and the ones with substitution of $10 \%$ (10SPV) and 15\% (15SPV) of alfalfa hay for sweet potato vines. The coefficients of digestibility of dry matter were $51.47 \%$ (0SPV), 52.07\% (10SPV) and $57.41 \%$ (15SPV); coefficients of digestibility of mineral matter, 15.17\% (0SPV), 17.06\% (10SPV) and $16.47 \%$ (15SPV); coefficients of digestibility of crude protein, $87.51 \%$ (0SPV), 84\% (10SPV) and $83.79 \%$ (15SPV); coefficients of digestibility of neutral detergent fiber, $20.25 \%$ (OSPV), $19.65 \%$ (10SPV) and $24.48 \%$ (15SPV); coefficients of digestibility of acid detergent fiber, $16.06 \%$ (OSPV), $16.82 \%$ (10SPV) and $22.36 \%$ (15SPV). The conclusion is that sweet potato vines can replace at least $15 \%$ of alfalfa hay in growing meat rabbits diets.
\end{abstract}

Keyword: growing rabbits, animal nutrition, by-products

\section{RESUMO}

Nos países em desenvolvimento, a produção animal é afetada pela dependência de ingredientes convencionais ou pelo alto custo, sendo importante pesquisar subprodutos agroindustriais. Deste modo, o objetivo deste estudo foi avaliar a digestibilidade de dietas para coelhos com baraço de batata-doce em substituição ao feno de alfafa. Um ensaio biológico foi realizado para determinar a digestibilidade do baraço de batata-doce, que levou 12 dias (5 para adaptação e 7 para coleta de fezes). Um total de 27 coelhos receberam três dietas diferentes: referência (0BBD) e aquelas com substituição de 10\% (10BBD) e 15\% (15BBD) de feno de alfafa por baraço de batata-doce. Os coeficientes de digestibilidade da matéria seca foram $51,47 \%$ (0BBD), 52,07\% (10BBD) e 57,41\% (15BBD); coeficientes de digestibilidade da matéria mineral, 15,17\% (0BBD), 17,06\% (10BBD) e 16,47\% (15BBD); coeficientes de digestibilidade da proteína bruta, 87,51\% (0BBD), 84\% (10BBD) e 83,79\% (15BBD); coeficientes de 
digestibilidade da fibra em detergente neutro, 20,25\% (0BBD), $19,65 \%$ (10BBD) e $24,48 \%$ (15BBD); coeficientes de digestibilidade da fibra em detergente ácido, 16,06\% (0BBD), $16,82 \%$ (10BBD) e $22,36 \%$ (15BBD). A conclusão é que o baraço de batata-doce pode substituir em até $15 \%$ o feno de alfafa nas dietas para coelhos em crescimento.

Palavras-chave: coelhos em crescimento, nutrição animal, subprodutos

\section{RESUMEN}

En los países en desarrollo, la producción animal se ve afectada por la dependencia de los ingredientes convencionales o por su alto costo, por lo que es importante investigar los subproductos agroindustriales. Por lo tanto, el propósito de este estudio fue evaluar la digestibilidad de las dietas para conejos con vides de camote, en sustitución del heno de alfalfa. Se realizó un ensayo biológico para determinar la digestibilidad de las hojas de batata-dulce, que tardó 12 días (5 para la adaptación y 7 para la recolección de heces). Un total de 27 conejos recibieron tres dietas diferentes: referencia (0HBD) y las que sustituyeron el 10\% (10BD) y el $15 \%$ (15HBD) de heno de alfalfa por las vides de batata. Los coeficientes de digestibilidad de la materia seca fueron $51.47 \%$ (OHBD), $52.07 \%$ (10BD) y $57.41 \%$ (15HBD); coeficientes de digestibilidad de la materia mineral, $15.17 \%$ (0HBD), $17.06 \%$ (10HBD) y $16.47 \%$ (15HBD); coeficientes de digestibilidad de la proteína cruda, $87.51 \%$ (0HBD), 84\% (10BD) y $83.79 \%$ (15HBD); coeficientes de digestibilidad de la fibra detergente neutra, 20.25\% (0HBD), $19.65 \%$ (10HBD) y $24.48 \%$ (15HBD); coeficientes de digestibilidad de la fibra detergente ácida, $16.06 \%$ (0HBD), $16.82 \%$ (10HBD) y $22.36 \%$ (15HBD). La conclusión es que las vides de batata pueden reemplazar al menos el $15 \%$ del heno de alfalfa en las dietas de conejos de carne en crecimiento

Palabras-clave: conejos en crecimiento, nutrición animal, subproductos

\section{Introduction}

In developing countries, animal production is hardly affected by the dependence on importation of the main food ingredients, as soybean meal, alfalfa and corn (LOUNACI-OUYED et al. 2014), or by the high cost of this ingredients. Considering the production of growing rabbit's meat, the costs about nutrition are the highest ones because the main ingredients are cultivated (KLINGER and TOLEDO, 2016). For example, alfalfa hay is the most expensive ingredient and the one with the highest incorporation percentage
(30\%). Therefore, it is important to search for alternative and local ingredients to substitute alfalfa hay, such as agroindustrial by-products.

All species can receive agroindustrial by-products as a diet constituent, but herbivores present better intake of these ingredients (KLINGER and TOLEDO, 2016). For rabbits, the inclusion of byproducts is viable because of the particularities in their digestive system (CHEEKE, 1987) - rabbits have a functional cecum that produces cecotrophes, a material rich in proteins, 
minerals and vitamins from microbial fermentation, which is ingested by the animals. The top of vegetables, such as sweet potato vines, can be used as byproducts. Sweet potato vines do not have trade value, and they are not part of Brazilian nutrition, so environmental liabilities are produced.

Recent researches have shown the importance of by products (VOLPATO et al. 2015) which are very abundant in Brazil as a result of its intense agricultural production. In the same country, the production of sweet potato is large because it is used in culinary human and, more recently, in fuel production (GONÇALVES NETO et al., 2011). Researchers from different countries have studied the effect of sweet potato vines as an alternative to reduce environmental liabilities and the final costs of products (TAMIR and TSEGA, 2010; NGUYEN and NGUYEN, 2012; LOCHMANN, et al. 2013). Although, data about sweet potato vines inclusion in diets for rabbits are still scarce. Therefore, the purpose to this study was to evaluate the digestibility of diets for rabbits with sweet potato vines, in substitution to alfalfa hay.

\section{Materials and methods}

The biological essay was executed in the Rabbit Breeding Laboratory at the Federal University of Santa Maria (UFSM Santa Maria, RS, Brazil), located at $29^{\circ} 68^{\prime}$ $\mathrm{S}$ of latitude and $53^{\circ} 80^{\prime} \mathrm{W}$ of longitude. The experimental period occurred during June, when the temperatures varied from $16^{\circ} \mathrm{C}$ to $25^{\circ} \mathrm{C}$. A group of 27 , mixed-sex, White New Zeland rabbits were used, after they were weaned at 35 days old, with average initial weight of $755.5 \mathrm{~g}$. The animals were allocated, individually, in cages with a measure of $50 \times 50 \times 50 \mathrm{~cm}$, which were equipped with individual bowls - one for water, another for food - and a tray for feces collect.

Three experimental diets were formulated (Table 1): reference diet (OSPV), without sweet potato vines; 10SPV, experimental diet with $10 \%$ of sweet potato vines in substitution to alfalfa hay; and 15SPV, experimental diet with $15 \%$ of sweet potato vines in substitution to alfalfa hay. The vitamin and mineral premix used was devoid of growth promoter, anticoccidial or antibiotic, with the purpose to avoid interference from these products in the animals digestion.

The digestibility essay took 12 days:

5 for adaptation and 7 for feces collect, according to European reference method for 
in vivo determination of diet digestibility in rabbits (PEREZ et al., 1995). The nonpelletized food and the water were served ad libitum during all the experiment. The feces of each animal were totally collected twice a day, at $08 \mathrm{am}$ and at $05 \mathrm{pm}$, and kept in bags which were stored in a $-10^{\circ} \mathrm{C}$ freezer.

Table 1 - Ingredients and chemical composition (\%) of the diets, for growing meat rabbits, with crescent substitution of alfalfa hay for sweet potato vines

\begin{tabular}{|c|c|c|c|}
\hline \multirow{2}{*}{ Ingredients } & \multicolumn{3}{|c|}{ Experimental Diets } \\
\hline & OSPV & 10SPV & $15 \mathrm{SPV}$ \\
\hline Corn & 17.25 & 17.25 & 17.25 \\
\hline Wheat meal & 25.00 & 25.00 & 25.00 \\
\hline Soy-bean meal & 17.50 & 17.50 & 18.00 \\
\hline Soy-bean oil & 2.50 & 2.50 & 2.40 \\
\hline Rice hull & 6.00 & 6.00 & 5.45 \\
\hline Alfalfa hay & 30.00 & 27.00 & 25.50 \\
\hline Sweet potato vines & - & 3.00 & 4.50 \\
\hline Dicalcium phosphate & 0.80 & 0.80 & 0.80 \\
\hline Calcitic limestone & 0.25 & 0.25 & 0.40 \\
\hline Salt & 0.50 & 0.50 & 0.50 \\
\hline $\begin{array}{l}\text { Mineral and vitaminic } \\
\text { supplement* }\end{array}$ & 0.20 & 0.20 & 0.20 \\
\hline \multicolumn{4}{|c|}{ Nutritional levels in dry matter } \\
\hline Crude Protein $(\%)$ & 17.25 & 16.81 & 16.60 \\
\hline Ether Extract (\%) & 4.39 & 4.58 & 4.67 \\
\hline Acid Detergent Fiber (\%) & 20.78 & 19.84 & 18.05 \\
\hline Neutral Detergent Fiber (\%) & 35.30 & 33.37 & 31.10 \\
\hline Calcium (\%) & 1.15 & 1.00 & 1.00 \\
\hline Phosphorus (\%) & 0.60 & 0.54 & 0.52 \\
\hline \multicolumn{4}{|c|}{$\begin{array}{l}\text { 0SPV: treatment without sweet potato vines; 10SPV: treatment with } 10 \% \text { of sweet potato vines in } \\
\text { substitution of alfalfa hay; 15SPV: treatment with 15\% of sweet potato vines in substitution of alfalfa } \\
\text { hay. *Composition in kg: Vitamin A } 600.000 \mathrm{IU} \text {; Vitamin D } 100.000 \mathrm{IU} \text {; Vitamin E } 8.000 \text {; Vitamin K3 } \\
200 \mathrm{mg} \text {; Vitamin B } 1.400 \mathrm{mg} \text {; Vitamin B2 } 600 \mathrm{mg} \text {; Vitamin B6 } 200 \mathrm{mg} \text {; Vitamin B12 } 2.000 \mathrm{mg} \text {; } \\
\text { Pantothenic Acid } 2.000 \mathrm{mg} \text {; Choline } 70.000 \mathrm{mg} \text {; Fe } 8.000 \mathrm{mg} \text {; Cu } 1.200 \mathrm{mg} \text {; Co } 200 \mathrm{mg} \text {; Mn } 8.600 \mathrm{mg} \text {; } \\
\text { Zn } 12.000 \mathrm{mg} \text {; I } 65 \mathrm{mg} \text {; Se } 16 \mathrm{mg} \text {. }\end{array}$} \\
\hline
\end{tabular}


Chemical analysis took place at the Bromatology Laboratory from the Pisciculture Laboratory of the Federal University of Santa Maria (UFSM - Santa Maria, RS, Brazil). The samples of diets and feces were prepared for analysis of chemical composition. The feces of each animal were dried in a forced ventilation kiln, at $55^{\circ} \mathrm{C}$, during 72 hours. After this, the samples were processed in a mill with $1 \mathrm{~mm}$ strainer, and they were verified about dry matter (DM), organic matter (OM), crude protein (CP), neutral detergent fiber (NDF) and acid detergent fiber (ADF). Finally, the coefficients of apparent digestibility were calculated for dry matter (CDDM), mineral matter (CDMM), crude protein (CDCP), neutral detergent fiber (CDNDF) and acid detergent fiber (CDADF) for each experimental diet.
Randomized allocation design was used, with 3 treatments and 9 repetitions. The means were compared by variance analysis, at a level of $5 \%$ significance. Then, theses values, found in the analysis, were submitted to regression equations.

\section{Results and discussion}

According to the results in Figure 1, the apparent digestibility of DM was superior in 15SPV experimental diet, with a coefficient of digestibility (CDDM) of $57.42 \%$. The worst result showed up in OSPV diet (51.47\%), and the intermediary value came from 10SPV diet (52.07\%). All these results are considered without the record of any digestive disturb during the biological essay.

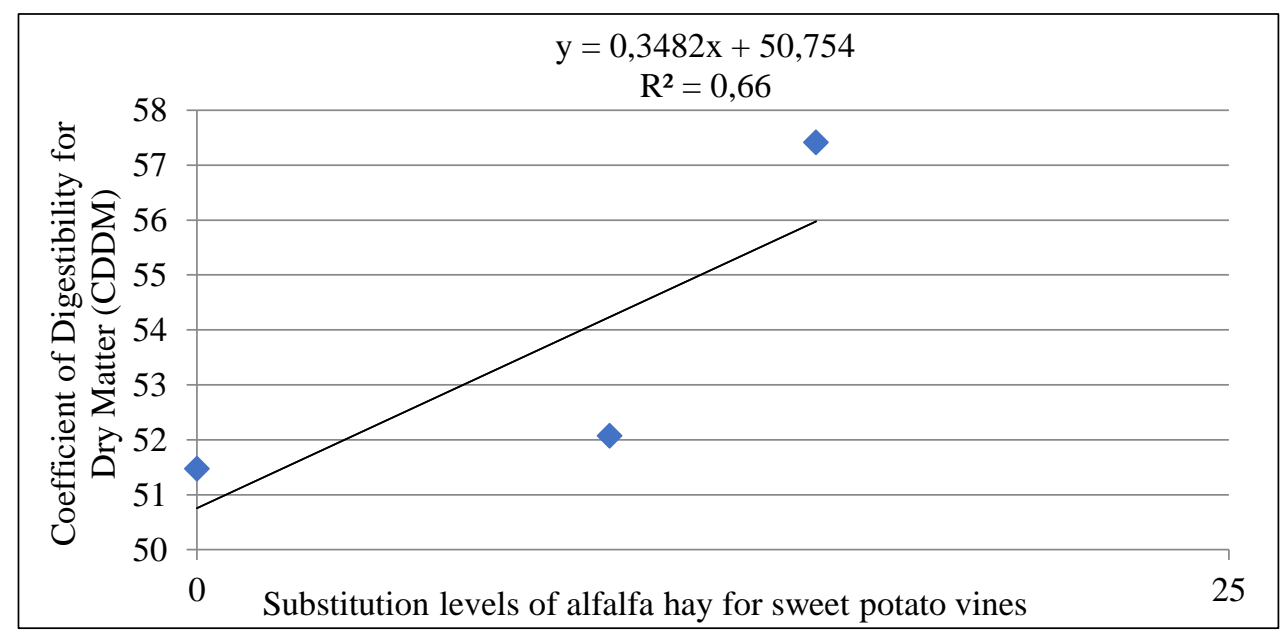


Figure 1 - Coefficient of digestibility of dry matter (CDDM) in diets with sweet potato vines in substitution to alfalfa hay diets.

The effect of the fiber source upon digestibility of dry matter and organic matter is directly related to the characteristics of the cell wall in the fibrous ingredient (CHEEKE, 1995; DEBLAS and WISEMAN, 1998 apud ARRUDA et al., 2002). Even though the main fiber source in rabbit nutrition is alfalfa hay, this food has interferences in its cell wall, but it does not reduce nutritional qualities. Although, the results suggest that sweet potato vines may have provided longer retention time, higher nutrients availability and better fiber degradation by microbial activity due to sweet potato vines are less lignified.

The coefficient of digestibility for mineral matter (CDMM), compared to the reference diet, was higher in the 10SPV diet, with $17.06 \%$. For the OSPV, the CDMM was $15.17 \%$ and $16.47 \%$ for $15 \mathrm{SPV}$ diet as it is shown in Figure 2. Alfalfa hay is an excellent source of calcium and magnesium, while some by-products, mainly the ones that are originated from grains grinding, provide a good amount of phosphorus (CHEEKE, 1987). The Ca:P proportion, in all experimental diets, was not different among them, and it is close to 2:1. Many factors interfere in digestibility and absorption of this fraction, as minerals availability according to their source, water quantity in the mineral source and the tendency of some mineral to absorb water and to get hard (CHEEKE, 1987).

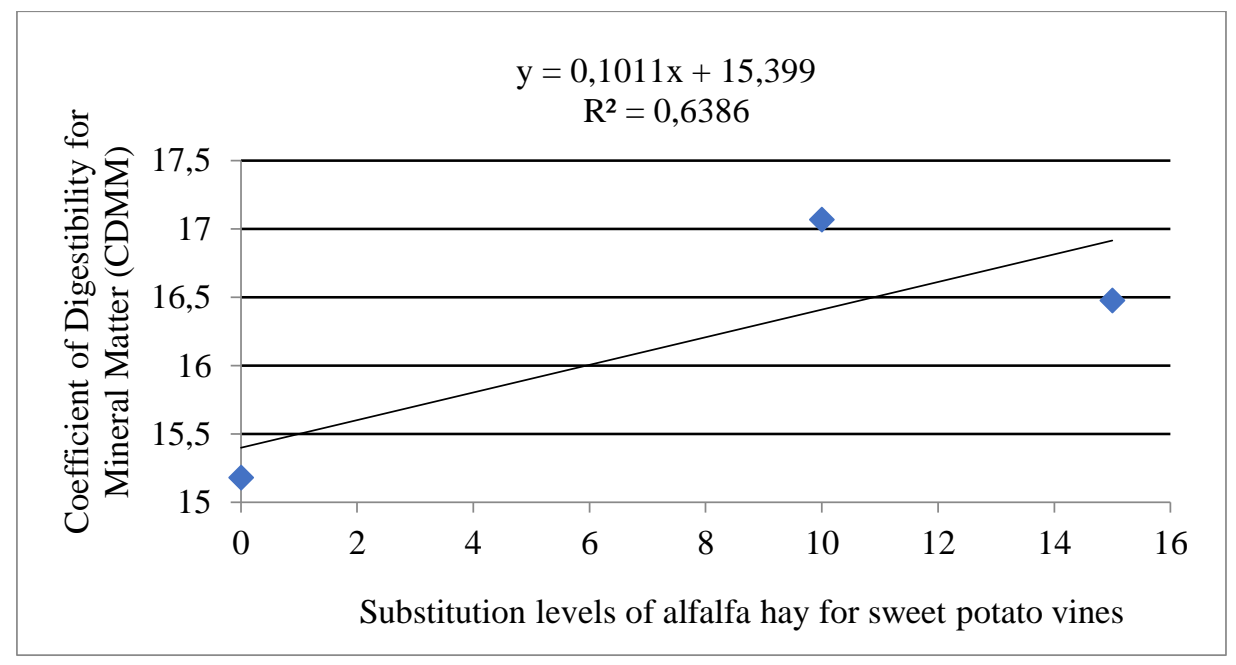

Figure 2 - Coefficient of digestibility of mineral matter (CDMM) in diets with sweet potato vines in substitution to alfalfa hay. 
Crude protein digestibility was a better utilized by the animals with OSPV diet $(87.51 \%)$, the worst result was found among the animals with 15SPV diet $(83.79 \%)$, and the average utilization was presented by the animals with 10SPV diet (84\%). This negative effect upon the digestibility of crude protein for the animals with 10SPV and 15SPV diets confirms the capacity of the rabbit to use protein from forage ingredients, as alfalfa hay, with better efficiency (FARIA et al, 2008). Furthermore, the addition of sweet potato vines reduces the fraction of crude protein in the diet (TAMIR and TSEGA, 2010). The coefficients for crude protein fraction (CDCP) are shown in Figure 3.

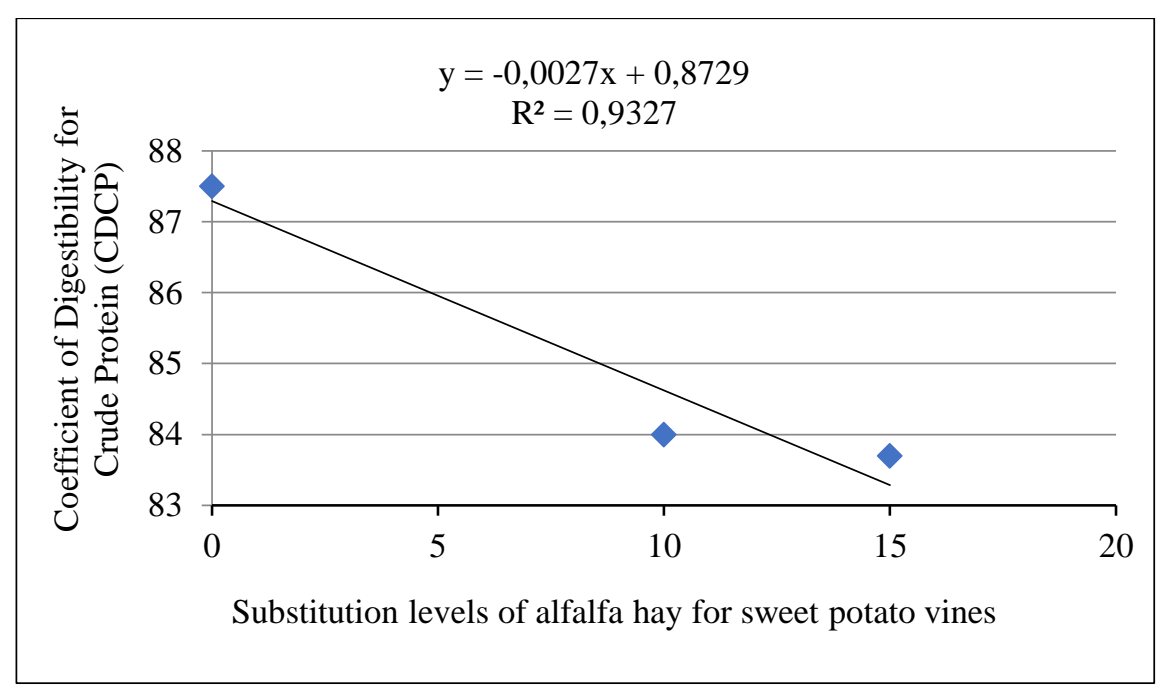

Figure 3 - Coefficient of digestibility of crude protein (CDCP) in diets with sweet potato vines in substitution to alfalfa hay.

Finally, for the fibrous fraction, the highest coefficient of digestibility for neutral detergent fiber (CDNDF) was presented in the 15SPV diet $(24.48 \%)$, whereas 10SPV diet had the lowest coefficient $(19.65 \%)$, as it is shown in
Figure 4. For the acid detergent fiber, the coefficient of digestibility (CDADF) was crescent, from the OSPV (16.06\%), with the lowest value, to 15SPV diet (22.36\%), with the highest value as shown in Figure 5. 
Revista Brasileira de Cunicultura, v. 18, novembro de 2020 - Disponível em:

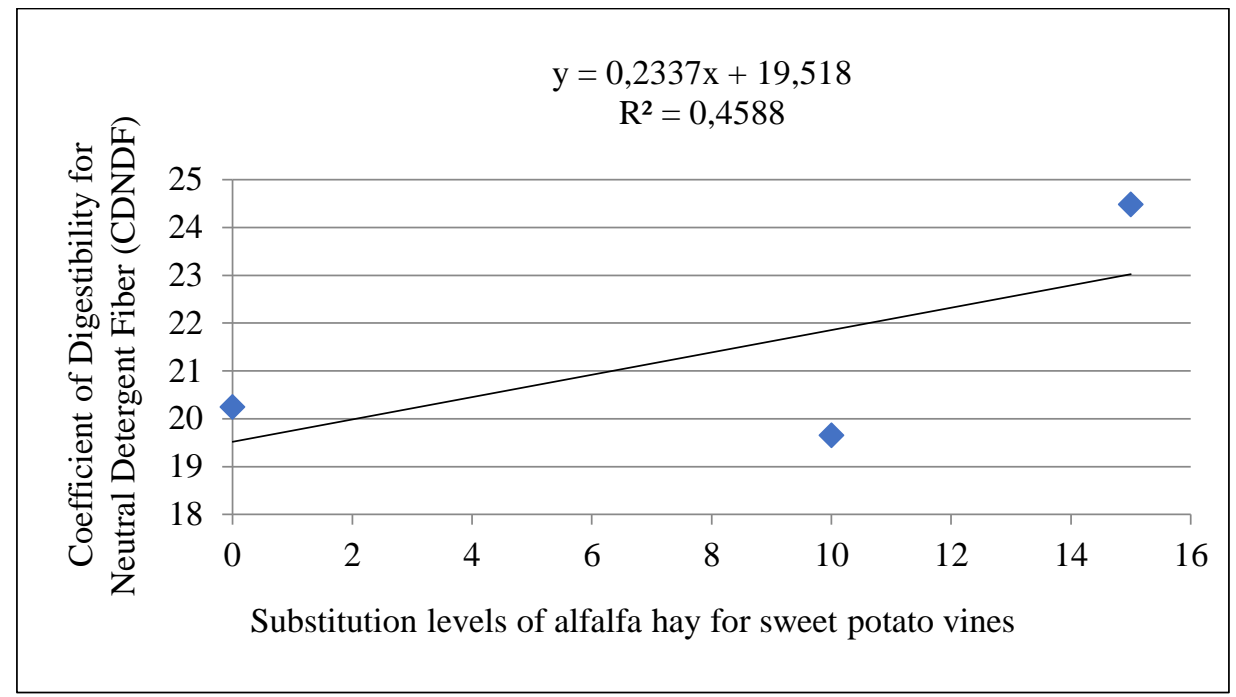

Figure 4 - Coefficient of digestibility of neutral detergent fiber (CDNDF) in diets with sweet potato vines in substitution to alfalfa hay.

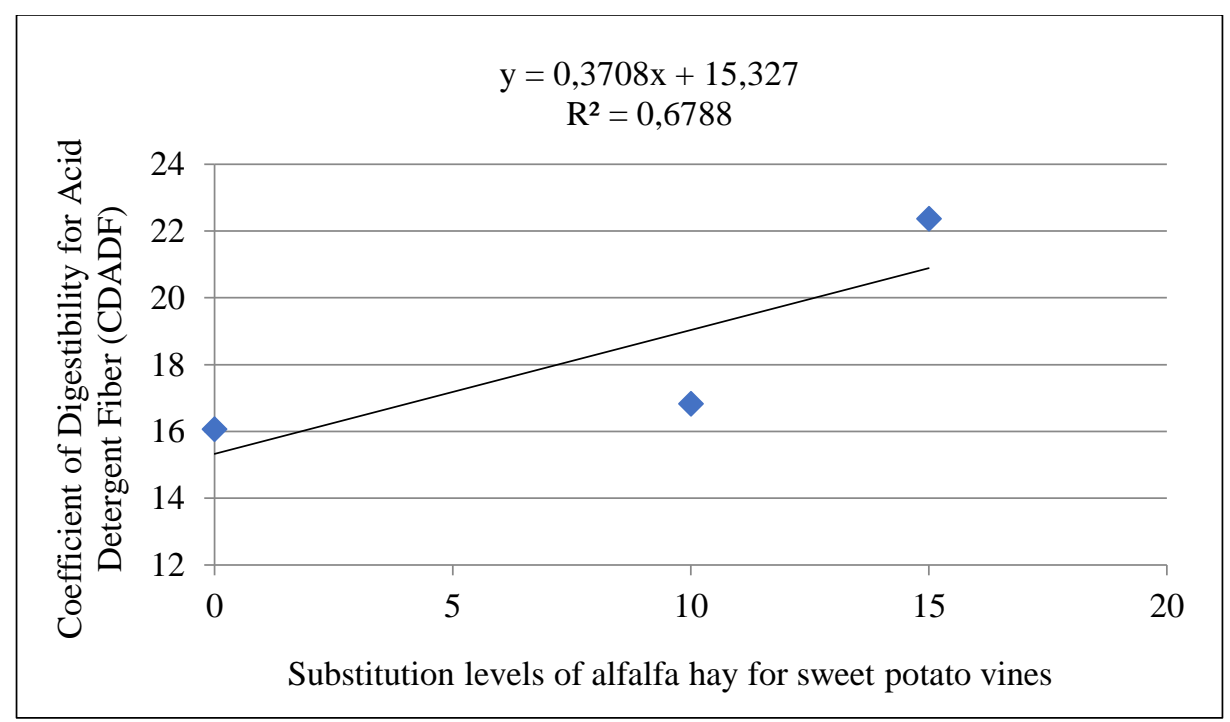

Figure 5 - Coefficient of digestibility of acid detergent fiber (CDADF) in diets with sweet potato vines in substitution to alfalfa hay.

A factor that interferes in fiber utilization is the density and the capacity of water absorption. Alfalfa soaks a great amount of water that makes it swollen, bigger and harder (CHEEKE, 1987). Because of that, 15SPV diet may have presented a better result in coefficient of digestibility for NDF and ADF. Furthermore, higher proportions of starch in the diet contribute to improve the digestibility of the fibrous fraction because of the supply of an ingredient balanced in 
energy, which helps to increase microbial activity and to degrade the fibrous fraction (ARRUDA et al., 2002).

Recent research also reveals the relation between sweet potato vines substitution - taking place for alfalfa hay with performance parameters, as weight gain, food intake, feed:gain ratio, carcass characteristics and liver weight in meat growing rabbits (KLINGER et al., 2016). The results evidence that weight gain, daily food intake and feed:gain ratio were not statistically different for the three experimental diets, with the same substitution percentage as in this research $0 \%, 10 \%$ and $15 \%$ of sweet potato vines. The results $-1941.25 \mathrm{~g}$ of final weight at 84 days old, $982.67 \mathrm{~g}$ of hot carcass weight, $83.88 \mathrm{~g}$ of daily food intake and $3.55 \mathrm{~g}$ of feed:gain ration - confirm that it is possible to substitute up to $15 \%$ of alfalfa hay for sweet potato vines.

\section{Conclusion}

It was concluded, after this research, that sweet potato vines can substitute at least $15 \%$ of alfalfa hay, totalizing $4.5 \%$ of the diet, without any losses to the animals, and with costs reduction.

\section{References}

ARRUDA, A. M. V.; LOPES, D. C.; FERREIRA, W. M.; et al. Digestibilidade Aparente dos Nutrientes de Rações Contendo Diferentes Fontes de Fibra e Níveis de Amido com Coelhos em Crescimento. Revista Brasileira de Zootecnia, v.31, n.3, p.1166-1175, 2002.

CHEEKE, P. R. Rabbit Feeding and Nutrition. London, GL: Academic Press, 1987.

FARIA, H. G.; FERREIRA, W. M.; SCAPINELLO, C.; OLIVEIRA, C. E. Efeito da utilização de dietas simplificadas, à base de forragem, sobre a digestibilidade e o desempenho de coelhos Nova Zelândia. Revista Brasileira de Zootecnia, v.37, n.10, p.1797-1801, 2008.

GONÇALVES NETO, A. C.; MALUF, W. R.; GOMES, L. A. A.; et al. Aptidões de genótipos de batata-doce para consumo humano, produção de etanol e alimentação animal. Pesquisa Agropecuária Brasileira, v.46, n.11, p.1513-1520, 2011.

KLINGER, A. C. K.; SILVA, L. P.; TOLEDO, G. S. P.; et al. Effect of sweet potato vines on performance parameters and some carcass characteristics of rabbits. 
Journal of Animal Physiology and Animal Nutrition, v.102, n.1, p.152-156, 2016.

KLINGER, A. C. K.; TOLEDO, G. S. P. Ingredientes não convencionais na nutrição cunícola no Brasil - Uma revisão. Revista Brasileira de Cunicultura, v.9, n.1, p.1-6, 2016.

LOCHMANN, R. T.; ISLAM, S.; PHILLIPS, H.; ADAM, Z; EVERETTE, J. Effects of dietary sweet potato leaf meal on the growth, non-specific immune responses, total phenols and antioxidant capacity in channel catfish (Ictalurus punctatus). Journal of the Science of Food and Agriculture, v.93, p.1365-1369, 2013.

\section{LOUNAOUCI-OUYED,}

G.;

BERCHICHE, M.; GIDENNE, T. Effects of substitution of soybean meal-alfalfamaize by a combination of field bean or pea with hard wheat bran on digestion and growth performance in rabbit in Algeria. World Rabbit Science, v.22, p.137-146, 2014.

NGUYEN, T. K. D.; NGUYEN, V. T. A response of nutrient intake, digestibility and growth rate of rabbits (Orcytolaguc cuniculus) fed water spinach or sweet potato vines with or without fiber supplement. Can Tho University Journal of Science, v.3, p.19-24, 2012.

PEREZ, J. M.; LEBAS, F.; GIDENNE, T.; et al. European reference method for in vivo determination of diet digestibility in rabbits. World Rabbit Science, v.3, n.3, p.41-43, 1995.

TAMIR, B.; TSEGA, W. Effects of different levels of dried sweet potato (Ipomoea batatas) leaves inclusion in finisher ration on feed intake, growth and carcass yield performance of Ross broiler chicks. Tropical Animal Health and Production, v.42, n.4, p.687-695, 2010.

VOLPATO, R. M.; OLIVEIRA, V.; GEWEHR, C. E.; PEREZ NETO, D. Coprodutos da agroindústria na alimentação de leitões. Ciência Rural, v.45, n.1, p.86-91. 